\title{
Pengolahan Limbah Tahu dan Tempe dengan Metode Teknologi Tepat Guna Saringan Pasir sebagai Kajian Mata Kuliah Pengetahuan Lingkungan
}

\author{
Muh. Azhari \\ Program Studi Teknik Lingkungan Universitas Muhammadiyah Palangkaraya \\ email: arymuh@gmail.com
}

\begin{abstract}
ABSTRAK. Limbah yang dihasilkan dari industri tahu dan tempe diantaranya limbah cair, limbah padat, dan limbah gas. Salah satu limbah tersebut seperti limbah cair tahu dan tempe jika tidak dikelola dengan baik akan menjadi permasalahan lingkungan yang membutuhkan waktu, tenaga, dan biaya dalam menangani masalah limbah cair tersebut. Pengolahan limbah tahu dan tempe dengan metode teknologi tepat guna saringan pasir menggunakan material diantaranya seperti pasir, arang sekam padi, kain katun dan kapur dengan menyiapkan 3 (tiga) buah tabung paralon dengan panjang 150 (seratus lima puluh) $\mathrm{cm}$ dan lebar 2,5 inci, yang digunakan secara bergantian pada limbah cair tahu dan tempe. Masing-masing tabung paralon diprevarasi menggunakan pasir, arang sekam padi, dan kapur dengan perbandingan campuran media saring $1: 1: 1$ yaitu pasir, kapur, dan arang sekam padi serta kain katun. Kemiringan tabung paralon saat melakukan proses saringan limbah cair adalah $30^{\circ}$. Dapat meminimalisir sifat fisik limbah cair menjadi lebih baik. Sifat fisik limbah cair tersebut diantaranya seperti warna, bau, rasa, kekentalan, kekeruhan, dan temperatur.
\end{abstract}

Kata kunci : limbah cair, tahu tempe, saringan pasir, teknologi tepat guna

\section{PENDAHULUAN}

Lingkungan merupakan jumlah semua benda hidup dan mati serta seluruh kondisi yang ada di dalam ruang yang ditempati. Secara garis besar, ada 2 (dua) macam lingkungan yaitu lingkungan fisik (abiotik) dan biotik. Lingkungan fisik (abiotik) adalah segala benda mati dan keadaan fisik yang ada di sekitar individu-individu misalnya: batubatuan, mineral, air, udara, unsur-unsur iklim, cuaca, suhu, kelembaban, angin, faktor gaya berat, dan lain-lain. Sedangkan, lingkungan biotik adalah segala makhluk hidup yang ada di sekitar individu baik tumbuh-tumbuhan, hewan, dan manusia. Tiap unsur biotik ini berinteraksi antar biotik dan juga dengan lingkungan fisik (abiotik).
Lingkungan biotik maupun abiotik selalu mengalami perubahan, baik secara tibatiba maupun perlahan-lahan. Perubahan tersebut sangat erat hubungannya dengan ekosistem yang mempunyai stabilitas tertentu. Makin besar keanekaragaman jenis hutan di daerah tropis yang mengandung banyak aneka ragam tumbuh-tumbuhan dan hewan di dalamnya makin besar pula peluang bagi kelestarian lingkungan tersebut, contohnya pada aktivitas pembuatan tahu dan tempe.

Bahan utama yang digunakan dalam pembuatan tahu dan tempe adalah kacang kedelai yang merupakan sumber makanan yang dapat diperoleh dengan harga murah serta mengandung protein tinggi. Proses pengolahan tahu dan tempe selalu menghasilkan limbah baik padat maupun 
limbah cair. Limbah adalah bahan yang berlebihan yang tidak memiliki nilai ekonomi. Limbah padat yang dihasilkan dalam proses produksi tahu dan tempe berupa daun pisang atau plastik, sedangkan limbah cair yang dihasilkan berupa padatan tersuspensi dan bahan organik terlarut yang banyak mengandung protein dan asam amino yang dapat menganggu lingkungan khususnya kualitas fisik air di lingkungan pemukiman masyarakat.

Pemantauan lingkungan adalah pengukuran pada komponen atau parameter lingkungan yang dilakukan secara berulangulang (periodik) untuk mengetahui adanya perubahan lingkungan akibat adanya kegiatan proyek atau industri rumah tangga seperti pembuatan tahu dan tempe. Produsen tahu dan tempe yang belum mengerti akan kebersihan serta kelestarian lingkungan serta tingkat ekonomi yang masih rendah penyebab pengolahan limbah cair tidak ditangani secara tepat bahkan dianggap menjadi beban yang cukup berat. Keberadaan industri tahu dan tempe harus selalu didukung baik oleh pemerintah maupun oleh masyarakat karena makanan tahu dan tempe merupakan makanan yang digemari oleh hampir seluruh lapisan masyarakat Indonesia, disamping nilai gizinya tinggi serta mudah dijangkau oleh masyarakat.

Limbah cair yang dihasilkan dari industri tahu dan tempe sebelum dibuang ke lingkungan haruslah dilakukan pengolahan terlebih dahulu. Hal ini dimaksudkan agar limbah cair tersebut tidak mencemari lingkungan dan kualitas lingkungan yang sehat tetap terjaga. Limbah yang berasal dari industri olahan makanan, merupakan tempat yang subur untuk berkembangbiaknya mikroorganisme, terutama mikroba pathogen. Mikroba patogen yang berkembangbiak dalam air tercemar menyebabkan timbulnya berbagai penyakit dan semuanya merupakan penyakit yang dapat menular dengan mudah. Kelestarian lingkungan bergantung pada kualitas lingkungan itu sendiri, dengan catatan dapat memberikan daya dukung yang optimal bagi kelangsungan hidup manusia, hewan dan tumbuhan di suatu wilayah.
Alternatif pengolahan limbah yang bisa dilakukan adalah dengan menggunakan saringan yang di prevarasi dengan campuran pasir, arang sekam padi, dan kapur. Campuran media tersebut yang selanjutnya dalam penelitian ini disebut sebagai metode teknologi tepat guna.

Kelebihan atau potensi masing masing material adalah sebagai berikut:

1. Pasir berfungsi sebagai material penyaring partikel-partikel yang ada dalam sumber air yang keruh secara fisik akan tertahan oleh lapisan pasir.

2. Arang sekam padi berfungsi menyerap zatzat yang mengotori air, juga menyerap bau serta warna sehingga menghasilkan air jernih.

3. Kain katun berfungsi membersihkan air dari kotoran dan organisme yang ada di dalam air keruh.

4. Kapur bekerja mengatur keasaman air agar menjadi netral ( $\mathrm{pH} 7$ - 8).

Oleh karena itu, atas dasar inilah dilakukan penelitian mengenai "Pengolahan Limbah Tahu dan Tempe dengan Metode Teknologi Tepat Guna Saringan pasir sebagai Kajian Mata Kuliah Pengetahuan lingkungan.”

\section{METODE PENELITIAN Alat dan Bahan}

Alat yang digunakan dalam penelitian ini adalah Kertas label, Alat tulis menulis, Tabung paralon, Mikroskop, Rak tabung reaksi, Kaca benda cekung, Kaca penutup, Pipet tetes, Tabung reaksi, Kawat saring, Lampu neon, Senter, Open kue, Gelas arloji, Botol film, Pelor sepeda motor, Stopwatch, Kompor, Lampu spiritus, Toples, Jaring, dan Kamera. Adapun bahan yang digunakan dalam penelitian adalah arang sekam padi, pasir, dan kapur serta limbah cair tahu dan tempe setelah 12 jam dihasilkan dan menunjukkan perubahan fisik seperti bau, dan perubahan warna.

\section{Prosedur Penelitian}

Berdasarkan alat dan bahan yang akan digunakan dalam penelitian ini maka peneliti melakukan prosedur penelitian sebagai berikut: 
1. Menyiapkan 3 (tiga) buah tabung paralon dengan panjang 150 (seratus lima puluh) $\mathrm{cm}$ dan lebar 2,5 inc, yang digunakan secara bergantian pada limbah cair tahu dan tempe. Masing-masing tabung paralon diprevarasi menggunakan pasir, arang sekam padi, dan kapur dengan perbandingan campuran media saring $1: 1$ : 1 yaitu pasir, kapur, dan arang sekam padi serta kain katun. Kemiringan tabung paralon saat melakukan proses saringan limbah cair adalah $30^{\circ}$.

2. Sampel saringan pasir yang diprevarasi dengan pasir, kapur, dan arang sekam padi serta kain katun ini akan dilakukan pengulangan sebanyak 3 (tiga) kali ulangan pada perlakuan yang diberikan.

3. Saringan pasir yang dibuat pada ke 3 (tiga) buah tabung paralon tersebut di prevarasi dengan cara sebagai berikut:

a. Pada ujung tabung paralon diikat kain katun sebagai penyaring sekaligus penahan agar pasir tidak terbawa limbah cair tahu dan tempe perlakuan ini dilakukan pada setiap dasar tabung paralon.

b. Saringan pasir yang diprevarasi dengan beberapa suplemen diantaranya arang sekam padi, dan kapur masing-masing bahan saringan yang akan digunakan adalah 1 (satu) kilogram pada perlakuan dan ulangan yaitu tabung paralon diisi dengan pasir dibagian paling atas kemudian kapur dan yang dibagian paling bawah adalah arang sekam padi serta kain katun

4. Setelah limbah cair tersebut disaring dengan prevarasi saringan pasir tersebut masing-masing filtrat disimpan dengan kantung plastic atau botol film serta dimasukkan ke dalam toples.

5. Jumlah toples yang digunakan dalam penelitian ini adalah 2 (dua) buah toples yang ukuran 2 (dua) liter 1 (satu) buah toples untuk limbah cair tahu yang sudah disaring dengan saringan pasir dan 1 (satu) buah toples untuk limbah cair tempe yang sudah disaring dengan saringan pasir.

6. Menguji filtrat yang sudah dihasilkan mengenai sifat fisik dan biologis antara lain bau, warna, kekentalan, kekeruhan, dan temperatur serta ada tidaknya mikroorganisme didalam limbah cair tahu dan tempe dengan cara sebagai berikut:

a. Pengujian pertama yang dilakukan peneliti adalah pengujian bau pada masing-masing sampel limbah cair yang sudah disaring di dalam toples menggunakan indra penciuman dengan cara mengkalibrasi indra penciuman menggunakan air jernih hal ini dilakukan setiap akan mencium bau masing masing sampel limbah cair dan dibantu oleh beberapa orang selain peneliti sendiri.

b. Menguji warna limbah cair tahu dan tempe menggunakan indra penglihatan pada setiap sampel filtrat.

c. Mengukur temperatur masing-masing filtrat menggunakan thermometer.

d. Menguji kekentalan filtrat menggunakan tabung kaca dari lampu neon dengan jumlah 3 (tiga) buah yang digunakan secara bergantian pada filtrat limbah cair tahu dan tempe, pelor sepeda motor dengan jumlah 3 (tiga) biji. Mengukur waktu yang diperlukan pelor mencapai dasar tabung dengan stopwatch. Pengujian ini juga bisa menggunakan indra.

e. Menguji kekeruhan filtrat dengan indra.

f. Melakukan pengujian sifat biologis limbah cair tahu dan tempe di bawah mikroskop dengan langkah berikut:

1) Pengambilan sampel limbah cair tahu dan tempe setelah 12 (dua belas) jam dihasilkan dalam pembuatan tahu dan tempe serta belum diberikan perlakuan apapun.

2) Sampel limbah yang sudah diambil disimpan di dalam tabung reaksi.

3) Menggunakan 6 (enam) buah tabung reaksi yaitu 3 (tiga) buah tabung reaksi untuk sampel filtrat limbah cair tahu dan 3 (tiga) tabung reaksi untuk sampel filtrat limbah cair tempe

4) Mengambil sampel masing-masing filtrat limbah cair yang akan diamati dibawah miroskop menggunakan pipet tetes yang berbeda pada setiap 
sampel limbah cair tahu dan tempe serta menggunakan kaca benda cekung dengan kaca penutup.

5) Setiap melakukan pengamatan limbah cair tahu dan tempe menggunakan kaca benda cekung serta kaca penutup yang digunakan dilewatkan di atas lampu spiritus agar steril.

6) Penetesan sampel limbah cair dalam pengujian sifat biologis menggunakan metode tetesan bergantung.

7) Mengamati masing-masing sampel dibawah mikroskop serta menentukan ada tidaknya mikroorganisme di dalam limbah cair tahu dan tempe.

8) Mengumpulkan data-data yang diperoleh dalam penelitian serta memberikan kesimpulan dari hasil penelitian yang telah dilakukan oleh peneliti mengenai sifat fisik dan biologis limbah cair tahu dan tempe.

g. Pencatatan data hasil pengamatan

Data hasil pengamatan di catat dalam tabel pengamatan yang dilampirkan oleh peneliti yaitu mengenai sifat fisik limbah cair tahu dan tempe diantaranya adalah bau, warna, $\mathrm{pH}$, temperatur, kekentalan, dan kekeruhan.

\section{HASIL DAN PEMBAHASAN}

Limbah cair tahu dan tempe memiliki warna, busa, endapan, bau yang sangat menyengat. Perubahan sifat fisik limbah tersebut terjadi setelah 12 (dua belas) jam. Untuk itu diperlukan sebuah cara untuk meminimalisir dampak yang ditimbulkan oleh limbah cair tahu dan tempe tersebut. Diantaranya dengan cara pengolahan limbah tahu dan tempe dengan metode teknologi tepat guna saringan pasir.

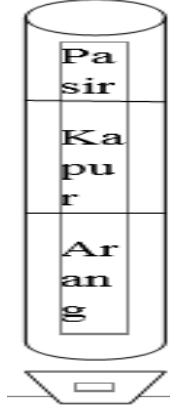

Gambar 1. Ilustrasi desain saringan pasir

Diantara sifat fisik limbah yang diteliti adalah bau, warna, temperatur, kekeruhan, dan kekentalan.

a. Bau

Bau merupakan sesuatu yang dapat dirasai oleh indra penciuman seperti anyir, busuk, sedap, dan harum. Adapun data hasil penelitian mengenai bau limbah cair tahu dan tempe dirangkum dalam Tabel 1.

Tabel 1. Bau limbah cair tahu dan tempe

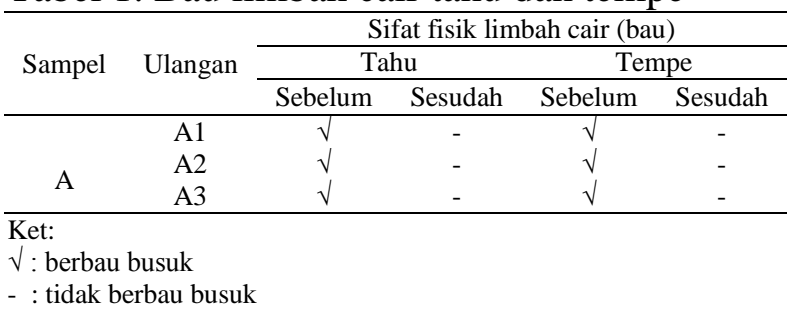

Bau pada limbah tahu dan tempe berkurang setelah disaring dengan saringan pasir yang diprevarasi dengan suplemen arang sekam padi dan kapur. Bau limbah hasil saringan juga hilang jikia dibiarkan lebih dari 6 (enam) hari. Bau limbah cair tahu dan tempe sebelum disaring memiliki bau yang busuk, anyir, atau tidak sedap sedangkan limbah cair tahu dan tempe hasil penyaringan juga masih memiliki bau akan tetapi baunya tidak setajam bau limbah cair tahu dan tempe sebelum disaring. Bau ini disebabkan oleh molekul-molekul organik seperti lipoksidase yang tidak bisa disaring secara efektif oleh saringan pasir dengan suplemen arang sekam padi.

Sifat bau limbah tersebut juga disebabkan adanya zat-zat organik yang telah terurai dalam limbah sehingga mengeluarkan gas-gas seperti sulfida amoniak, nitrogen, sulfur dan fospor yang berasal dari pembusukan protein yang dikandung limbah. Bau yang keluar dari dalam air dapat 
langsung berasal dari bahan buangan atau air limbah dari kegiatan industri, atau dapat pula berasal dari hasil degradasi bahan buangan oleh mikroba yang hidup didalam air. Bahan buangan industri yang bersifat organik atau bahan buangan dan air limbah dari kegiatan industri pengolahan bahan makanan seringkali menimbulkan bau yang sangat menyengat. Mikroba di dalam air akan mengubah bahan organik, terutama gugus protein, secara degradasi menjadi bahan yang mudah menguap dan berbau.

Berkurangnya bau sampel limbah setelah disaring mengindikasikan berkurangnya jumlah partikel organik. Indikator berkurangnya partikel organik yang terlarut dalam limbah setelah disaring diantaranya adalah berkurangnya bau, hilangnya bau setelah beberapa hari dan berkurang jumlah atau tekanan gas pada limbah seperti yang dikatakan bahwa mikroorganisme akan tumbuh subur pada limbah yang banyak mengandung senyawasenyawa organik. Mikroorganisme akan mendekomposisi (mengurai) senyawa organik tersebut dan menghasilkan senyawa atau gas buangan. Dengan demikian berkurangnya bau dan tekanan gas peneliti jadikan sebagai indikator berkurangnya partikel organik pada sampel hasil saringan.

\section{b. Warna}

Warna limbah cair tahu adalah kuning sedangkan limbah cair tempe berwarna coklat muda. Adapun data hasil penelitian mengenai keadaan warna limbah cair tahu dan tempe adalah seperti yang terdapat pada Tabel 2 .

Tabel 2. Warna limbah cair tahu dan tempe

\begin{tabular}{cccccc}
\hline \multirow{3}{*}{ Sampel } & \multirow{2}{*}{ Ulangan } & \multicolumn{4}{c}{ Sifat fisik limbah cair (warna) } \\
\cline { 3 - 6 } & & \multicolumn{3}{c}{ Tahu } & \multicolumn{2}{c}{ Tempe } \\
\cline { 3 - 6 } & & Sebelum & Sesudah & Sebelum & Sesudah \\
\hline \multirow{3}{*}{ A } & A2 & $\sqrt{ }$ & - & $\sqrt{ }$ & - \\
& A3 & $\sqrt{ }$ & - & $\sqrt{ }$ & - \\
& A3 & $\sqrt{ }$ & & - \\
\hline \multirow{4}{*}{} & Ket: & & & \\
& $\sqrt{ }$ & = berwarna kuning & &
\end{tabular}

Warna dalam air disebabkan adanya ion-ion logam besi dan mangan (secara alami), humus, plankton, tanaman air dan buangan industri. Warna timbul akibat suatu bahan terlarut atau tersuspensi dalam air, di samping adanya bahan pewarna tertentu yang kemungkinan mengandung logam berat.
Warna limbah cair tahu dan tempe sebelum disaring dengan saringan pasir adalah kuning sedangkan limbah cair tempe berwarna coklat muda. Warna limbah cair tahu dan tempe setelah disaring tampak bening. Setelah melakukan beberapa kali pengulangan, filtrat yang dihasilkan tetap memiliki warna yang sama atau tidak menimbulkan kejenuhan pada saringan pasir dan suplemen arang sekam padi yang digunakan.

Berubahnya warna setelah penyaringan sebagai indikator berkurangnya partikelpartikel organik dan anorganik yang terlarut dalam sampel. Berkurangnya partikel-partikel ini karena sebagian terserap dan atau tertahan oleh partikel penyaring. Pasir dengan ukuran 0,0001-0,0003 mm, sekam padi dan kapur dapat menahan partikel-partikel yang berukuran besar. Selain itu arang sekam padi yang merupakan karbon berstruktur amorf dan bersipat basa dapat mengabsorb zat-zat pewarna dan ion-ion logam. Demikian juga untuk kapur, dapat menetralkan asam dan menyerap zat warna serta ion-ion tertentu. Dengan alasan inilah warna setelah perlakuan penyaringan menjadi berkurang.

Bahan buangan dari kegiatan industri yang berupa bahan anorganik dan bahan organik seringkali dapat larut didalam air. Apabila bahan buangan dan air limbah industri dapat larut dalam air maka akan terjadi perubahan warna air. Air dalam keadaan normal dan bersih tidak akan berwarna, sehingga tampak bening dan jernih. Air normal yang dapat digunakan untuk suatu kehidupan pada umumnya tidak berwarna.

\section{c. Temperatur}

Temperatur dalam kamus bahasa Indonesia berarti suhu. Adapun data hasil penelitian mengenai temperatur limbah cair tahu dan tempe dirangkum dalam Tabel 3.

Tabel 3. Temperatur.

\begin{tabular}{|c|c|c|c|c|c|}
\hline \multirow{3}{*}{ Sampel } & \multirow{3}{*}{ Ulangan } & \multicolumn{4}{|c|}{ Sifat fisik limbah cair (suhu) } \\
\hline & & \multicolumn{2}{|c|}{ Tahu } & \multicolumn{2}{|c|}{ Tempe } \\
\hline & & Sebelum & Sesudah & Sebelum & Sesudah \\
\hline \multirow[b]{3}{*}{ A } & A1 & $22^{\circ} \mathrm{C}$ & $21^{\circ} \mathrm{C}$ & $21^{\circ} \mathrm{C}$ & $24^{\circ} \mathrm{C}$ \\
\hline & $\mathrm{A} 2$ & $22^{\circ} \mathrm{C}$ & $23^{\circ} \mathrm{C}$ & $21^{\circ} \mathrm{C}$ & $24^{\circ} \mathrm{C}$ \\
\hline & A3 & $22^{\circ} \mathrm{C}$ & $23^{\circ} \mathrm{C}$ & $21^{\circ} \mathrm{C}$ & $25^{\circ} \mathrm{C}$ \\
\hline
\end{tabular}

Suhu atau temperatur sangat berpengaruh terhadap sifat fisik limbah yang lain seperti bau, warna, kekentalan, dan 
kekeruhan. Dengan adanya suhu pada limbah tahu dan tempe tersebut akan mendukung aktivitas kehidupan mikroorganisme yang berfungsi mendekomposisikan bahan organik yang tersuspensi didalam limbah cair. Suhu merupakan sifat fisik yang dapat menghubungkan ekologi dengan kebutuhan nutrisi mikroorganisme baik yang saprofit maupun yang parasit. Pada penelitian ini pengukuran suhu atau temperatur menggunakan thermometer. Suhu limbah cair tahu dan tempe sebelum disaring berkisar antara $21^{\circ} \mathrm{C}-22^{\circ} \mathrm{C}$. Limbah cair tahu dan tempe setelah saringan penyaringan berkisar $21^{\circ} \mathrm{C}-25^{\circ} \mathrm{C}$. Berarti pada suhu kisaran $21^{\circ} \mathrm{C}$ $25^{\circ} \mathrm{C}$ merupakan suhu yang masih bisa terjadi kehidupan mikroorganisme karena dari suhu $10^{\circ} \mathrm{C}-85^{\circ} \mathrm{C}$ mikroorganisme pathogen masih bisa melakukan pertumbuhan.

Peningkatan suhu dapat sebagai indikator adanya aktivitas kimiawi dan biologis oleh mikroorganisme. Dari bahasan indikator sebelumnya (bau, warna) peneliti simpulkan bahwa partikel dalam sampel hasil saringan berkurang. Walaupun suhu diakibatkan oleh panas yang dilepaskan dari aktivitas kimiawi penguraian atau dekomposisi senyawa organik oleh mikroorganisme, namun menurut peneliti kenaikan suhu ini tidak disebabkan oleh aktivitas kimiawi atau biologi dari partikel terlarut. Hal ini berdasarkan bahasan sebelumnya bahwa bau dan tekanan gas berkurang serta warna menjadi bening mengindikasikan berkurangnya partikel terlarut. Oleh karena itu menurut peneliti kenaikan suhu ini diakibatkan oleh partikel penyaring. Diketahui bahwa partikel padat (partikel penyaring) suhunya lebih tinggi dari suhu zat cair (limbah), selain itu partikel kapur jika terlarut dalam air akan bereaksi menghasilkan basa $\mathrm{Ca}(\mathrm{OH})_{2}$ dan melepaskan panas. Jadi peningkatan suhu ini akibat dari partikel padat atau dari kapur tersebut.

\section{d. Kekentalan}

Kekentalan berasal dari kata kental yang memperoleh awalan ke dan akhiran an, kental merupakan sifat yang tidak terlalu encer. Adapun data hasil penelitian mengenai kekentalan limbah cair tahu dan tempe terdapat pada Tabel 4 .

Tabel 4. Kekentalan

\begin{tabular}{|c|c|c|c|c|c|}
\hline \multirow{3}{*}{ Sampel } & \multirow{3}{*}{ Ulangan } & \multicolumn{4}{|c|}{ Sifat fisik limbah cair (kekentalan) } \\
\hline & & \multicolumn{2}{|c|}{ Tahu } & \multicolumn{2}{|c|}{ Tempe } \\
\hline & & Sebelum & Sesudah & Sebelum & Sesudah \\
\hline \multirow{3}{*}{ A } & A1 & $\sqrt{ }$ & - & $\sqrt{ }$ & - \\
\hline & A2 & $\sqrt{ }$ & - & $\sqrt{ }$ & - \\
\hline & A3 & $\sqrt{ }$ & - & $\sqrt{ }$ & - \\
\hline
\end{tabular}

Kekentalan limbah cair tahu dan tempe diperoleh dengan menggunakan indra, setelah melakukan penyaringan menggunakan saringan pasir. Dari hasil pengamatan menunjukkan, bahwa limbah cair tersebut tidak kental melainkan encer seperti air biasa karena bahan organik yang tersuspensi di dalam limbah cair tersebut berhasil disaring dan mengendap di atas permukaan pasir. Kekentalan terdiri dari bahan padat organik maupun anorganik yang larut, mengendap maupun tersuspensi. Bahan ini akan mengendap pada dasar air yang lama kelamaan menimbulkan pendangkalan pada dasar badan penerima. Akibat lain dari kekentalan ini menimbulkan tumbuhnya tanaman air tertentu dan dapat menjadi racun bagi makhluk lain. Kekentalan menunjukkan banyaknya lumpur terkandung dalam limbah air.

Kekentalan atau banyaknya endapan dan koloidal serta bahan yang terlarut berasal dari adanya bahan buangan industri yang berbentuk padat. Bahan buangan industri yang berbentuk padat kalau tidak dapat larut sempurna akan mengendap di dasar sungai dan yang dapat larut sebagian akan menjadi koloidal. Endapan sebelum sampai ke dasar sungai akan melayang di dalam air dan menghalangi masuknya sinar matahari ke dalam lapisan air. Padahal sinar matahari sangat diperlukan oleh mikroorganisme untuk melakukan fotosintesis. Karena tidak ada sinar matahari maka proses fotosintesis tidak dapat berlangsung. Akibatnya, kehidupan mikroorganisme menjadi terganggu.

Apabila endapan dan koloidal yang terjadi berasal dari bahan buangan organik, maka mikroorganisme, dengan bantuan oksigen yang terlarut di dalam air, akan melakukan degradasi bahan organik tersebut 
sehingga menjadi bahan yang lebih sederhana. Dalam hal ini kandungan oksigen dalam air akan berkurang sehingga organisme lain yang memerlukan akan terganggu pula. Maka dari itu, pembuangan limbah tahu dan tempe oleh para pengrajin tidak diperhatikan dengan baik, serta kurangnya pemahaman dan ilmu mengenai kesehatan lingkungan maka ketidakstabilan atau kerusakan akan terjadi seperti pencemaran air.

\section{e. Kekeruhan}

Kekeruhan berasal dari kata keruh yang diberikan awalan ke dan akhiran an. Kekeruhan merupakan keadaan tentang air yang kotor dan tidak jernih, buram, tidak bening atau keadaan keruh. Adapun data hasil penelitian mengenai kekeruhan limbah cair tahu dan tempe dirangkum dalam Tabel 5.

Tabel 5. Kekeruhan

\begin{tabular}{|c|c|c|c|c|c|}
\hline \multirow{3}{*}{ Sampel } & \multirow{3}{*}{ Ulangan } & \multicolumn{4}{|c|}{ Sifat fisik limbah cair (kekeruhan) } \\
\hline & & \multicolumn{2}{|c|}{ Tahu } & \multicolumn{2}{|c|}{ Tempe } \\
\hline & & Sebelum & Sesudah & Sebelum & Sesudah \\
\hline \multirow{3}{*}{ A } & A1 & $\sqrt{ }$ & - & $\sqrt{ }$ & - \\
\hline & A2 & $\sqrt{ }$ & - & $\sqrt{ }$ & - \\
\hline & A3 & $\sqrt{ }$ & - & $\sqrt{ }$ & - \\
\hline $\begin{array}{l}\text { Ket: } \\
\sqrt{ }=\text { ker } \\
\text { - = tidal }\end{array}$ & ruh & & & & \\
\hline
\end{tabular}

Kekeruhan merupakan keadaan air yang kotor dan tidak jernih, buram, tidak bening atau keruh. Kondisi limbah cair sebelum disaring adalah keruh. Penyaringan limbah cair tahu dan tempe menggunakan saringan pasir diperoleh sampel air tidak keruh karena air limbah yang sudah disaring tersebut bersifat optik serta bahan organik yang ada di dalam limbah tersebut sudah tidak ada. Kekeruhan menunjukkan sifat optis air yang menyebabkan pembiasan cahaya ke dalam air.

Kekeruhan membatasi pencahayaan ke dalam air karena gaya tarik menarik antar molekul yang terjadi antara benda-benda yang bersentuhan. Sekalipun ada pengaruh padatan terlarut atau partikel yang melayang dalam air namun penyerapan cahaya dipengaruhi bentuk dan ukurannya. Kekeruhan terjadi karena adanya bahan terapung dan terurainya zat tertentu seperti bahan organik, jasad renik, lumpur, tanah liat dan benda lain yang melayang ataupun terapung dan sangat halus. Sifat keruh air dapat dilihat dengan mata secara langsung karena ada partikel koloidal (diameter 10-8 $\mu \mathrm{mm}$ ) yang terdiri dari kwartz, tanah liat, sisa bahan-bahan, protein dan ganggang yang terdapat dalam limbah.

\section{KESIMPULAN}

Berdasarkan hasil analisis data dan pembahasan hasil penelitian, dapat ditarik kesimpulan bahwa:

1. Ada pengaruh pengolahan limbah tahu dan tempe menggunakan teknologi tepat guna saringan pasir dengan suplemen tambahan terhadap kualitas limbah cair terutama pada parameter fisik dan biologis.

2. Penelitian mengenai pengolahan limbah tahu dan tempe menggunakan teknologi tepat guna saringan pasir sebagai kajian mata kuliah pengetahuan lingkungan memang berpotensi berdasarkan hasil penelitian yang telah dilakukan serta silabus mata kuliah pengetahuan lingkungan khususnya mengenai polusi: Tanah, Air, Udara, dan Lingkungan serta Kesehatan.

\section{SARAN}

1. Kepada Pengelola Pabrik

Diharapkan kepada pemilik pabrik tahu dan tempe agar dalam melaksanakan proses produksi tahu dan tempe agar selalu memperhatikan mengenai limbah yang dihasilkan baik limbah cair, padat basah, padat kering, dan khususnya limbah cair, agar tidak membuang limbah tersebut ke lingkungan secara bebas.

2. Kepada Masyarakat

Diharapkan kepada masyarakat agar ikut berpartisipasi dalam menanggulangi limbah produksi tahu dan tempe untuk dapat meminimalisir dampak yang ditimbulkan oleh limbah tersebut, khususnya limbah cair tahu dan tempe.

3. Kepada Pemerintah

Diharapkan kepada pemerintah agar memberikan solusi dan arahan kepada pemilik pabrik tahu dan tempe khususnya serta masyarakat pada umumnya mengenai penanganan yang tepat atau pengolahan yang tepat terhadap limbah tahu dan tempe yang dihasilkan dalam produksi tahu dan tempe agar tidak mencemari lingkungan. 
4. Kepada Peneliti Lain

Bagi para peneliti lain diharapkan dapat melakukan penelitian lanjutan mengingat hasil yang diperoleh dalam pengolahan limbah tahu dan tempe mengggunakan metode teknologi tepat guna saringan pasir masih kurang supaya dapat memberikan solusi terhadap limbah cair tahu dan tempe yang dihasilkan dalam produksi kepada pemilik pabrik tahu dan tempe khususnya dan masyarakat pada umumnya.

\section{DAFTAR PUSTAKA}

Melati, F. F., 2007, Metode Sampling Bioekologi, Bumi Aksara, Jakarta.
Supardi, I., 2003, Lingkungan Hidup \& Kelestariannya, PT Alumni, Bandung.

Irianto, K., 2006, Mikrobiologi Jilid 1, Yrama Widya, Bandung.

Ginting, P., 2007, Sistem Pengelolaan Lingkungan dan Limbah Industri, Yrama Widya, Bandung.

Sadimin, 2007, Proses Pembuatan Tahu, CV. Sinar Cemerlang Abadi, Semarang.

Sugiharto, 1987, Dasar-Dasar Pengelolaan Air Limbah, Universitas Indonesia, Jakarta.

Wardhana, W. A., 2004, Dampak Pencemaran Lingkungan, Andi Offset, Yogyakarta. 